\title{
The geography of technology-intensive start-ups and venture capital:
}

\section{European evidence}

\author{
Massimiliano Guerini*, Francesca Tenca*
}

\begin{abstract}
* Politecnico di Milano, School of Management, Department of Management, Economics and Industrial Engineering, Via Lambruschini 4/b, 20156, Milano.
\end{abstract}

This is a post-peer-review, pre-copyedit version of an article published in Economia e Politica Industriale. The final authenticated version is available online at: http://dx.doi.org /10.1007/s40812-018-0098-9.

\begin{abstract}
This paper aims at providing novel evidence about the geographical concentration of venture capital (VC) activity in seven European countries. Drawing upon a unique dataset, VICO 2.0, we describe the geographical distribution of VC investments and VC-backed technology-intensive start-ups and analyse the regional and country-level factors associated to the regional concentration in VC activity. Results from econometric estimates suggest that regional VC activity is positively associated to the level of regional knowledge intensity, the level of regional human capital, the local supply of VC investors and a more favourable country's legal and institutional environment.
\end{abstract}

Keywords. Geography; technology-intensive start-ups; Venture Capital; Europe.

Acknowledgments. The authors acknowledge support from the "RISIS - Research infrastructures for the assessment of science, technology and innovation policy" project, funded by the European Union under the Seventh Framework Programme (Grant Agreement n³13082). 


\section{Introduction}

There is quite unanimous agreement among scholars and policy makers that young firms operating in technology intensive industries (hereafter: technology-intensive start-ups) contribute substantially to a country's international competiveness, as they are key engines of innovation, job creation and economic growth (e.g., Audretsch and Keilbach 2004; 2005; Criscuolo et al. 2014).

One of the main challenges that technology-intensive start-ups face is obtaining the funding they need in the early stage of their lives to develop their businesses and then to scale up (European Commission 2016). Indeed, the information asymmetries associated to the high technological content of these entrepreneurial ventures, the lack of a track record, and the low and mostly intangible value of their assets, which can hardly be pledged as collateral, hinder traditional financing forms (Berger and Udell 1990; Carpenter and Petersen 2002). Specialized financial intermediaries such as Venture Capital (hereafter: VC) investors are an important source of financing for technology-intensive statups. These investors are better able than traditional financial intermediaries to overcome information asymmetries that typically characterize technology-intensive start-ups (Bertoni et al. 2015a), and to provide value-added activities that are needed to scale-up, e.g., financial, administrative, marketing, strategic and managerial support (Gompers et al. 2001; Denis 2004).

However, entrepreneurs in different countries, and even in different geographical areas within the same country, may face substantially different conditions in their ability to access VC financing. Prior literature studying the geographical concentration of VC activity is mainly focused on the U.S. market. These contributions have primarily documented that VC investments are concentrated in very few regions, typically around economically and financially developed metropolitan centers, such as the Silicon Valley, the Boston area and New York (e.g., Chen et al. 2010; Cumming and Dai 2010; Lindgaard Christensen 2007). Other studies confirm similar patterns of agglomeration around the main urban centers in U.K. and China (e.g., Mason and Harrison 2002; Pan et al. 2016).

Despite the scholarly interest in this issue, a clear gap exists concerning the study of the patterns of geographical concentration in the context of the European VC market. Europe still experiences 
high fragmentation of VC activity across national borders (European Investment Fund 2016), with a substantial heterogeneity in terms of regional entrepreneurial activity (Audretsch and Belitski 2017) and institutional environments (Moore et al. 2015). Thus, with this paper we aim at advancing our knowledge concerning the geographical distribution of VC activity in Europe, by analysing whether different regional characteristics and/or country-specific institutional environments are associated to different regional agglomeration patterns of VC for technology-intensive start-ups. Specifically, we aim at answering the following research questions: 1) What are the main European hubs of VC activity (in terms of number of VC-backed technology-intensive start-ups, number of VC investments, and VC investment performance)? 2) Is the uneven geographical distribution of VC activity across European regions associated to specific local characteristics and country-specific institutional conditions?

To address these research questions, we use a sample of 3,896 technology-intensive start-ups located in seven European countries (Belgium, Finland, France, Germany, Italy, Spain, and United Kingdom), extracted from the VICO 2.0 database, a new data infrastructure developed in the context of the European project "RISIS, Research infrastructures for the assessment of science, technology and innovation policy" (RISIS) ${ }^{1}$.

Our results can be summarized as follows. First, we document cross-country differences in the number of technology-intensive start-ups that received VC and in the amount of VC investment deals. Second, we find that major hubs of VC activity are the metropolitan areas of London, Paris and Berlin. Third, in terms of early stage and exit performances of VC-backed start-ups, there are big disparities within countries. Fourth, we show that VC activity is strongly connected to the level of regional knowledge intensity, as measured by regional $\mathrm{R} \& \mathrm{D}$ expenditures and the local presence of top universities, the level of regional human capital, as measured by the percentage of employment in high-tech industries, the local supply of VC investors, and a more favourable country's legal and

\footnotetext{
${ }^{1}$ http://risis.eu.
} 
institutional environment.

The paper proceeds as follows. In section 2 we review the existing literature concerning the role of geography in VC. In section 3 we describe the data source and the sample selection process used in this study. In section 4 we present univariate analysis of the geographical distribution of technology-intensive start-ups, VC investment deals and investment performance across metropolitan areas. In section 5 we describe the methodology used for the multivariate analysis that relates regional VC activity to a set of regional and country-specific characteristics, and then we present the results of this empirical analysis. Section 6 concludes.

\section{Literature Review}

Prior research on the geography of VC activity has documented that differences in the institutional characteristics across countries play a prominent role in explaining differences in the level of VC activity. A favourable fiscal and legal environment facilitates $\mathrm{VC}$ funding and increases the general supply of equity capital (Armour and Cumming 2006). For instance, stronger investor's and creditor's legal protection (e.g., in case of bankruptcy), together with more transparent accounting standards, have a significant positive outcome on the governance of $\mathrm{VC}$ investments and the design of VC contracts. These institutional characteristics facilitate deal origination, thanks to a better access to information for investors, and deal syndication, alleviating the risks of harmful co-investments (Cumming et al. 2010). Moreover, available empirical evidence suggests a positive association between the volume of the VC market and the size and liquidity of a country's stock market, interpreted as proxies for better exit opportunities for VC investors (Gompers and Lerner 1999; 2001; Black and Gilson 1998; Jeng and Wells 2000; Mayer et al. 2005).

Despite the relevance of institutional characteristics in explaining differences in the level of VC activity across countries, it is also widely acknowledged that VC activity is extremely concentrated in very few VC “centers" or "hubs" within single countries (Chen et al. 2010; Cumming and Dai 2010; Lindgaard Christensen 2007; Florida and Smith 1993). In the U.S., more than half of VC offices 
are located just in three regions: the Silicon Valley, Massachusetts, and New York (Cumming and Dai 2010). In Canada, VC financing is directed predominantly towards three regions, Ontario, Quebec and British Columbia, where the largest financial and high-tech districts in the country are located, namely Toronto, Montreal, and Vancouver respectively (Florida and King 2015; Subhash 2007). Similarly, VC investors in the U.K. are concentrated in the Greater London area and in the South Eastern part of the country, at the expense of the peripheral regions, characterized by few local VC firms and a general lack of financial intermediaries (Martin et al. 2005; Mason and Harrison 2002; Mason and Pierrakis 2013). Also in the emerging Chinese VC market, investors appear to be agglomerated around few large metropolitan areas and the dominant financial centers of Beijing, Shenzhen and Shanghai (Zhang 2011; Pan et al. 2016).

When taking a closer look to the characteristics of main VC hubs, it emerges that VC investors and VC-backed start-ups tend to be co-located in technological clusters and in leading financial centers, being concentrated in geographical areas that are characterized by: i) a growing economy (Gompers and Lerner 1998); ii) a high level of innovation and entrepreneurial activity (Chen et al. 2010; Scheltrer 2003; Gompers and Lerner 1998); iii) higher success rates of past VC investments (Chen et al. 2010; Gompers et al. 2005); iv) dense urban environments, which facilitate direct and frequent interactions between investors and skilled human capital, for instance college graduates and/or people holding jobs in creative classes. With regard to this latter point, Florida and Mellander (2016) provide evidence of an increasing urban orientation of VC investment and start-up activity, resulting in a shift from relatively isolated suburbs of metropolitan areas (e.g., Silicon Valley) to highly interconnected city centers (e.g., San Francisco Bay Area).

Co-location of entrepreneurs and VC investors might be explained by the location bias of VC investors when making their investment decisions. Indeed, VC investors prefer to invest locally to reduce information asymmetry and transaction costs when selecting investments (Zook 2002; Florida and Smith 1993). Spatial proximity reduces transportation costs, allowing a 'hands-on' strategy, which involves direct monitoring and coaching activity (Bernstein et al. 2016; Lerner 2009). Previous 
empirical evidence has confirmed that VC investors are located close to their investee companies both in the U.S. (Chen et al. 2010; Gompers and Lerner 2005; Sorenson and Stuart 2001) and Europe (Bertoni et al. 2015b; Lutz et al. 2013). Spatial proximity, also, appears to be particularly important for deals involving very large investments and for less experienced VC investors (Lutz et al. 2013). Thus, entrepreneurs located in prominent VC hubs have a clear advantage in terms of access to VC financing with respect to those located in areas with a scarcity of VC supply, who, conversely, may face severe financial constraints. The lack of local VC investors is also not easily compensated by outside VC investors because the latter typically rely on the presence of a local partner with adequate screening and monitoring capabilities when they invest outside of their local environments (Devigne et al. 2013; Mäkelä and Maula 2008). Furthermore, in these areas entrepreneurs tend to self-select out of the VC market (demand side-selection), as they anticipate a higher competition with other entrepreneurs for obtaining the scarcely available VC funding. The limited number of entrepreneurs that seek funding, in turn, also discourages new VC investors from entering the local market (Bertoni et al. 2018). Hence, co-location of entrepreneurs and VC investors is a self-reinforcing mechanism.

We therefore expect, also in the European context, the existence of agglomeration patterns of VC activity in preferred locations. In what follows, we adopt an exploratory approach to provide evidence on what are main European hubs of VC activity (in terms of number of VC-backed technology-intensive start-ups, number of VC investments, and VC investment performance) and on the regional and country-level characteristics associated with the geographical concentration of VC activity.

\section{Data}

\subsection{Data source}

The source that we use to answer to our research questions is the VICO 2.0 database, developed in the context of the "RISIS, Research infrastructures for the assessment of science, technology and innovation policy" project. The VICO 2.0 database extends the existing VICO data infrastructure 
developed within a previous FP7 project called "VICO, Financing Entrepreneurial Ventures in Europe". ${ }^{2}$ The VICO 2.0 database contains geographical, industry and accounting information on 17,863 companies that i) have received at least one initial VC investment starting from 1/1/1998 up to the end of 2014, ii) have been incorporated after 1/1/1988 and iii) are located in seven European countries (namely Belgium, Finland, France, Germany, Italy, Spain, and the United Kingdom) and Israel. Thus, for each company born after 1/1/1998 the complete outside equity financial history is tracked up to 2014. At the investment deal level VICO 2.0 provides information on the deal date, the total amount invested, the number and the type of investors. Detailed information has been also collected for each company and investor, including company's and investor's industry sector, address, foundation date, company's exit (IPO or M\&A), and finally company's accounting information. The dataset contains 7,834 distinct investors, of which 6,182 VC investors. Companies and investors have been involved in 28,044 investment deals, for a total number of 52,657 investmentlevel observations (i.e. all the company-investor-round dyads), as several investors might be involved in the same investment deal (i.e. syndicated investment deals).

The advantage of using VICO 2.0 database relies in the combination of data extracted from three proprietary databases, namely Thompson One Private Equity, Zephyr, and Crunchbase. Thompson One Private Equity has been widely used in prior empirical research on VC (Da Rin et al. 2013). Nevertheless, some scholars have found that the coverage of VC activity in Thomson One Private Equity is rather incomplete, especially outside of the U.S. (e.g., Kaplar and Lerner 2016). In VICO 2.0, Thomson One Private Equity is the main source of information, accounting for 13,058 companies that received at least a $\mathrm{VC}$ investment. However, it is worth pointing out that the inclusion of data from Zephyr and Crunchbase allowed to significantly increase the coverage of VC-backed companies in the selected countries for a total of additional 4,805 companies (3,519 and 918 additional

\footnotetext{
${ }^{2}$ VICO has been used in several academic publications that have empirically investigated the impact of VC financing on start-up performance (e.g., Croce et al. 2013; Bertoni and Tykvová 2015; Colombo and Shafi 2016; Guerini and Quas 2016).
} 
companies from Zephyr and Crunchbase, respectively), which represent the $27 \%$ of the total number of companies included in VICO 2.0.

\subsection{Sample selection}

We identify technology-intensive start-ups in VICO 2.0 by applying the Eurostat definition of highand medium-high-technology manufacturing industries and high-technology knowledge-intensive services (based on the NACE Rev. 2 core codes at the 2 digits-level that are available in VICO 2.0). ${ }^{3}$ We restricted the total sample of VICO 2.0 companies to those incorporated after 1998 to assure a relevant definition of 'start-up' (Almeida et al. 2003). Moreover, we excluded companies located in Israel, as detailed geographical information on the Israeli market (e.g., at the regional and metropolitan level) was not available. The result is a total sample of 3,896 technology-intensive startups, involved in a total of 7,040 VC investment deals occurred in the period 1998-2014. ${ }^{4}$ Table 1 reports the distribution of sample firms by industry.

[Insert Table 1 around here]

About $85 \%$ of start-ups operate in knowledge-intensive services. More specifically, around 50\% of start-ups operate in "Computer programming, consultancy and related activities", around 20\% in "Scientific research and development", $8 \%$ in "Information service activities" and 5\% in "Telecommunications". As to manufacturing industries, around $6.5 \%$ of start-ups operate in the "Manufacture of computer, electronic and optical products" industry and 2.5\% in the "Manufacture of pharmaceutical products and preparations" industry. Medium-technological manufacturing industries represent only a small portion of the sample (about 6\%).

\footnotetext{
${ }^{3} \mathrm{http} / / /$ ec.europa.eu/eurostat/statistics-explained/index.php/Thematic_glossaries.

${ }^{4}$ As the main focus of this work is on the geography of VC-backed technology-intensive start-ups and VC investments, we also excluded from the analysis investments made by non-VC investors, such as business angels.
} 
Table 2 shows the number of technology-intensive start-ups, the number of $\mathrm{VC}$ investment deals and the total amount invested by VC firms in each country. As to the distribution of technologyintensive start-ups, most of them are located in the U.K. (37\%), Germany (25\%) and France (18\%), accounting for $80 \%$ of the sample. The remaining firms are distributed among Spain (7\%), Finland (7\%), Italy (4\%) and Belgium (3\%). As to the total amount invested, technology-intensive start-ups received VC funding for a total of $€ 33.3$ billion in 7,040 investment deals occurred in the period 1998-2014. The U.K. is the largest VC market in terms of both the number of investment deals and amount invested, with 2,770 investment deals and around $€ 15.5$ billons invested in local start-ups. Germany follows with $€ 7.5$ billion. France ranks third with more than $€ 5$ billion. At the bottom we find Italy and Finland, with less than $€ 1$ billion.

Table 3 reports mean and median deal values for a VC deal by country. Start-ups located in Belgium and Germany have been involved in larger investment deals, followed by Italy, U.K., and Spain. The size of a VC investment deal is particularly small in Finland (less than $€ 2$ million on average).

[Insert Table 2, 3 around here]

Figure 1 reports industry specialization patterns in the different countries, showing the Balassa indexes (Balassa 1965; 1989) for each industry and country. The index is calculated as the ratio between i) the share of technology-intensive start-ups (or VC investment deals) in the focal industry and in each country and ii) the share of technology-intensive start-ups (or VC investment deals) in the focal industry in the whole sample. Thus, values greater (smaller) than 1 indicate a higher (lower) specialization in the focal industry of a country compared to the whole sample. To compute the indexes, we used the same NACE industries identified in Table 1. For the sake of synthesis, we group together NACE rev. 2 industries 20, 27, 28, 29, 30 under the label "Other Manufacturing” and NACE rev. 2 services 59 and 60 under the label "Other Services". 
[Insert Figure 1 around here]

It emerges that the U.K. is specialized in knowledge-intensive services, notably in "Scientific research and development" and "Telecommunications", while it shows a relative lower specialization in manufacturing. Belgium (BE) is strongly specialized in "Manufacture of pharmaceutical products and preparations". Finland (FI) and Spain (ES) show a relative high concentration of start-ups in the “Computer programming, consultancy and related activities”. As to France, Figure 1 highlights a quite high concentration of both stat-ups and investment deals in "Manufacture of pharmaceutical products and preparations", "Manufacture of computer, electronic and optical products" and "Information service activities". "Information service activities" seem relevant in Germany (DE) as well, together with "Manufacture of computer, electronic and optical products". Finally, Italy (IT) is mainly focused on other manufacturing sectors and, to a lesser extent, on "Manufacture of pharmaceutical products and preparations" and "Telecommunications".

\section{Univariate analysis on the geographical concentration of VC activity}

In this section, we present univariate analysis of the geographical distribution of technology-intensive start-ups, VC investment deals and investment performance across Functional Urban Areas (FUAs). FUAs have been developed by OECD with the aim of increasing the international comparability of economic and social performances across metropolitan areas. The definition of FUA uses population density to identify urban cores and travel-to-work flows to identify the hinterlands, whose labour market is highly integrated with the cores (OECD 2013). Thus, FUAs allow to capture, better than cities, highly connected urban districts and suburban metropolitan areas, in terms of population, accessibility to human capital, and economic conditions. Figure 2, Figure 3 and Figure 4 show the distribution of technology-intensive start-ups in Northern Europe (without Finland), Finland and Southern Europe, respectively. 
[Insert Figure 2, 3, 4 around here]

Figure 2, 3 and 4 clearly show that VC-backed technology-intensive start-ups tend to agglomerate around main metropolitan areas. In the U.K., which ranks first in both the number of start-ups and the number of VC investment deals, there are three main technology-intensive clusters: around the London-Cambridge area in the South, Manchester in the Center and Edinburgh in the North. In Germany, the most relevant technology-intensive clusters are Berlin, Muenchen and Hamburg. In France, Paris ranks first, while the areas surrounding Lyon, Grenoble and Toulouse follow at long distance. In Spain, technology-intensive start-ups mainly concentrate in Barcelona and, secondly, Madrid. Conversely, in Italy and Finland start-ups are more distributed, but some agglomerations are found around Milan and Helsinki.

Figure 5 shows the details concerning the distribution of the number of technology-intensive start-ups and the number of VC investment deals in the top 20 FUAs, ranked by the number of startups.

[Insert Figure 5 around here]

The top 20 FUAs account for nearly $60 \%$ of the total number of start-ups. Start-ups and VC investment deals, in line with previous literature on the U.S. market, are indeed concentrated in few important metropolitan areas, such as London, Paris, Berlin, and Muenchen. Moreover, London is the main VC investment hub also in terms of VC investment amount, with $€ 6.3$ billion, followed by Paris (€3.0 billion), Berlin (€1.9) and Muenchen (€1.3). In the Finnish VC market, which is characterized by smaller VC deals in comparison to the other countries, Helsinki alone represents an important hub in terms of collected amount, with $€ 0.7$ billion.

Table 4 shows two indicators aimed at measuring start-up performance in the early and in the late stage for the top 10 FUAs (ranked by the number technology-intensive start-ups). As to the early stage, we use a growth indicator based on the combination of three measures: total assets, turnover 
and the number of employees. More specifically, in each geographical area, we identify the number of start-ups that after three years from the incorporation year reached: i) a total asset value greater than $€ 2$ million or ii) a turnover value greater than $€ 2$ million or iii) a number of employees greater than 20. ${ }^{5}$ Then, we divide this number by the total number of start-ups in each geographical area. This performance measure is aimed at capturing the growth of VC-backed start-ups in their early development phase. Instead, we measure late stage VC-backed start-ups' performance as the percentage, in each geographical area, of start-ups that achieved a successful exit in the period 19982014. A successful exit occurs whether the start-up goes public (IPO) or, alternatively, it is acquired by another firms (M\&A) (e.g., Guerini and Quas 2016).

[Insert Table 4 around here]

Cambridge and London are the best performers in terms of exit opportunities. Quite interestingly, start-ups located in Cambridge exhibit a performance that is $76 \%$ and $41 \%$ higher than the average performance of start-ups located in the U.K. in the early and late stage, respectively (in the U.K., the early stage growth indicator equals 22.0, while the late stage indicator equals 24.4). Instead, Edinburgh reports a worse performance than the average performance of U.K.-based start-ups for both early stage and late stage indicators. It is also worth noting how the performance of Muenchen and Madrid in the late stage (24.2 and 20.5, respectively) is much higher with respect to the average values registered at the country level (Germany: 17.0; Spain: 10.2).

Overall, the univariate analysis presented here demonstrates that there are some relevant disparities within countries, for instance between central (e.g., in terms of development of financial markets) and peripheral regions. We further explore these disparities in the following multivariate analysis.

\footnotetext{
${ }^{5}$ We used this approach in order to limit the problem of missing values for assets, turnover and number of employees.
} 


\section{Multivariate analysis on the geographical concentration of $\mathrm{VC}$ activity}

\subsection{Econometric specification}

To study the determinants of the geographical concentration of VC activity, we employ a number of econometric models that relates the number of VC investments and VC-backed start-ups at the regional level (NUTS2, according to the EUROSTAT classification of administrative regions) to a set of explanatory variables that focus on both regional and country-level characteristics. Unfortunately, longitudinal data at the FUA level for most explanatory variables are not available. We therefore use the NUTS 2 unit of analysis ${ }^{6}$ to avoid a high number of missing values when building regional explanatory variables.

More specifically, we consider two dependent variables: the number of VC investment deals in each NUTS2 region in each year (VC investments) and the number of VC-backed start-ups that received an initial investment in each NUTS2 region in each year (VC-backed start-ups).

As to explanatory variables, we use two sets of variables that can be broadly classified as: i) measures of regional development, and ii) measures on a country's fiscal, legal and cultural environment. As to the former, we consider the gross domestic product per capita (GDP per capita) in each region/year (source: Eurostat) as a proxy of average wealth at the regional level. We also take into account density effects, by including the number of inhabitants per square $\mathrm{km}$ (Population density) in each region/year (source: Eurostat) and a dummy variable (Metropolitan area), which equals one if, in the region, there is a large metropolitan area (i.e., a top 20 FUA). We also employ two measures of regional knowledge intensity: the level of $R \& D$ expenditures as a percentage of the GDP ( $R \& D$ expenditures) in each region/year (source: Eurostat) and the number of universities in each region ranked among the top 100 world universities according to the QS World University Ranking 2010 (Top university). Furthermore, as a proxy for the regional availability of skilled human capital in technology-intensive industries (Technology-intensive employment), we consider the

\footnotetext{
${ }^{6}$ We treat Greater London area at the NUTS1 level for comparability purposes.
} 
employment in high-technology manufacturing and knowledge-intensive services as a percentage of the total employment in each region/year (source: Eurostat). Furthermore, we consider the regional supply of $\mathrm{VC}$, by including the number of active $\mathrm{VC}$ firms (Active VCs), i.e. the number of $\mathrm{VC}$ investors that have made at least one investment in each region/year or, alternatively, the number of $\mathrm{VC}$ investors with an office in the region ( $V C$ offices). Finally, we include the ratio between governmental VC investments and total VC investments (GVC funding), cumulated over a 3-year period, in each region/year. This latter variable is a measure for the availability of local governmental VC funding in the region. Recent evidence suggests that governmental VC investors can play an important certification role in stimulating private $\mathrm{VC}$ investments in technology-intensive start-ups (Guerini and Quas 2016). Nevertheless, other contributions suggest that governmental funding may crowd out private VC investments (Cumming et al. 2017; Cumming and MacIntosh 2006; Armour and Cumming 2006).

As to country-specific variables related to the fiscal environment, we consider the level of taxation on income and capital gains (Tax) in each country/year (source: International Monetary Fund). For the legal and institutional framework, we consider the World Governance Index (Legal index) (source: World Bank). The choice of this measure has several advantages over other available institutional indexes, as it includes a comprehensive set of institutional dimensions, specifically government effectiveness (e.g., level of bureaucracy), voice and accountability (e.g., public access to information, freedom of expression), regulatory policies (e.g., quality of regulation on competition, banking/finance, trade), rule of law (e.g., enforcement of contracts, property rights protection), political stability, and control of corruption. Moreover, the index covers almost all the countries and years in our sample. The index has been computed as the average of these six institutional dimensions (e.g., Li and Zahra 2012) ${ }^{7}$, with higher values indicating better legal and institutional conditions.

\footnotetext{
${ }^{7}$ Alternatively, in unreported estimates we consider as a robustness check the country legal origin (La Porta et al. 1997, 1998): French, German, Scandinavian, or English. Results are available from the authors upon request.
} 
Furthermore, we control for the ease to start a business in each country, using the number of days required to start a new business (Time to start-up) in each country/year (Source: World Bank, Doing Business project) and the degree of development of the capital market, by including the ratio between the number of listed domestic companies and the GDP (Listed companies) in each country/year (Source: World Federation of Exchanges database). Finally, we consider the role of national cultural values (Li and Zahra 2012). Specifically, we include three cultural dimensions (Hofstede 1991) that are expected to be relevant in the context of VC: Uncertainty avoidance (the degree to which the members of a society feel uncomfortable with uncertainty and ambiguity), Individualism (the degree to which ties between individuals within a country are loose as opposed to countries in which people are integrated into strong, cohesive in-groups) and Long-term orientation (the degree to which people in a country encourage parsimony and efforts, in a pragmatic way, to prepare for the future as opposed to countries in which people prefer to maintain time-honoured traditions and norms, viewing societal change with suspicion).

In Table 5 we report the description for the dependent and independent variables, in Table 6 we provide summary statistics, while the correlation matrix is shown in Table 7.

[Insert Table 5, 6, 7 around here]

Given the panel structure of data and the count nature of our dependent variables, we estimate random effects negative binomial models (Hausman et al. 1984). These models take into account the clustering of observations by regions and allow that dispersion varies randomly across clusters. We include in all specifications year dummies (i.e., the years of investments) to account for unobserved year effects and address potential reverse causality by lagging all time-varying independent variables by one year. 


\subsection{Results from econometric estimates}

Table 8 and Table 9 show the results of random effects negative binomial models with the number of VC investments and the number of VC-backed technology intensive start-ups in each region/year as dependent variable, respectively. We report a number of alternative specifications, in order to avoid multicollinearity problems, as some variables show high correlations ${ }^{8}$. To ease the interpretation of coefficients, all the continuous explanatory variables have been standardized (zero mean, unit standard deviation). Accordingly, coefficients of continuous variables reported in Table 8 and Table 9 can be interpreted as percentage changes in dependent variable due to one standard deviation increase of explanatory variables.

Let us focus first on Table 8. As to regional level variables, we find a positive association between regional knowledge intensity and the number of $\mathrm{VC}$ investments. The variables $R \& D$ expenditures and Top university are indeed positive and statistically significant. An increase of one standard deviation in the level of $R \& D$ expenditures is associated to a boost in the level of regional $\mathrm{VC}$ investments ranging from $18 \%$ to $31 \%$, while the percentage change in the number of $\mathrm{VC}$ investments associated to one standard deviation increase of Top universities varies between $12 \%$ and $27 \%$. As to density effects, the coefficient of Metropolitan area is positive and highly statistically significant in all model specifications with a considerable magnitude: regions with large metropolitan areas exhibit a level of VC investments that is at least 129\% higher as compared to regions without metropolitan areas. Also the regional level of skilled human capital in technology-intensive industries (Technology-intensive employment) is always positive and significant, with an estimated magnitude of around 30\%. Considering the supply of $\mathrm{VC}$, the number of $\mathrm{VC}$ investments in a region is positively related to the local presence of Active $V C$ investors. When using, as an alternative measure for the local supply of VC, the number of VC offices, we do not find any statistically significant effect. This result might be explained by the fact that VC headquarters are mainly concentrated in large

\footnotetext{
${ }^{8}$ Variance Inflation Factor analysis confirm that multicollinearity is not a concern in reported results.
} 
metropolitan areas. Finally, we do not find any significant association between the regional share of governmental VC investments and the number of VC investment in the region.

When looking at country-level covariates, it emerges that the institutional framework matters in the geographical distribution of VC investments. Better formal institutions, captured by our composite measure of Legal index, are positively associated with the number of VC regional investments with a magnitude of around $28 \%$ for an increase of one standard deviation in the level of the Legal index. Moreover, a longer time required to start a new business is generally negatively associated with the number of regional VC investments. In addition, better exit opportunities for VC investors, captured by Listed companies, are associated to a higher number of regional VC investments in the models without the inclusion of cultural dimensions (with a magnitude 22\%-32\%), while when controlling for the influence of culture on the number of regional VC investments, Listed companies becomes not significant. Instead, we find that long term orientation is negatively correlated with VC activity. This is not surprising, as countries with highly developed financial markets, on average, score lower on long term orientation (e.g., U.K.). The other two cultural dimensions seem not to bear any significant effect.

[Insert Table 8 around here]

Let us now focus on Table 9, which shows the results of random effects negative binomial models, using as dependent variable the number of VC-backed start-ups in each region/year. Results are similar to those reported in Table 8 as to regional level variables concerning the presence of large metropolitan areas, knowledge intensity ( $R \& D$ expenditures and Top universities), skilled human capital (Technology-intensive employment) and Active VC. As to the local supply of VC, we now find a positive association (but weak in terms of statistical significance) between the number of VCbacked start-ups and the share of regional governmental VC. 
As to country-level variables, the coefficients of Legal index and Long-term orientation are in line with those reported in Table 8. Other country-level variables exhibit weakly significant (or nonsignificant) coefficients.

[Insert Table 9 around here]

\section{Conclusion}

In this paper we provided descriptive evidence on the geographical distribution of VC-backed technology-intensive start-ups and their funding patterns in seven European Countries. Moreover, we analysed the determinants of the geographical concentration of $\mathrm{VC}$ activity, giving for the first time a more comprehensive overview of the European VC industry. Key findings can be summarized as follows.

First, U.K. and Germany are the leading countries in terms of technology-intensive start-up creation, accounting for around 1/3 and 1/4 of the total number of technology-intensive VC-backed start-ups in the period 1998-2014. France follows closely.

Second, concerning the distribution of VC activity at the FUA level, we find that technologyintensive start-ups and VC investment deals are mainly concentrated around few big metropolitan areas, such as London, Paris and Berlin. These results are partially in line with previous evidence on VC activity (e.g., Mason and Harrison 2002; Mason and Pierrakis 2013), which found an uneven distribution of VC investments in the U.K., where London, the South-East and, partially, the East of England have been found to attract more than their expected shares of early stage VC (Mason and Pierrakis 2013). However, our study also demonstrates that the geography of VC activity in Europe is more nuanced, and not exclusively linked to the geography of leading financial centres. Some examples are Cambridge, Manchester, and Edinburgh areas in the U.K., Muenchen and Hamburg in Germany, and Lyon, Grenoble and Toulouse in France, which appear in the top 20 FUAs for number of VC-backed technology-intensive start-ups and VC investments deals. 
Third, when taking a closer look to the regional and country-level characteristics of the geographical distribution of VC activity, we found that knowledge intensive regions, with high-level of skilled human capital and presence of local VC investors are associated to a higher level of VC activity. Furthermore, favourable legal frameworks, exit opportunities and procedures that facilitate entrepreneurs in creating new businesses, play a key role. The role played by governmental VC initiatives remains less clear. On the one hand, our results suggest that the overall number of VC investments is not higher (nor lower) in regions characterized by a high share of governmental VC. On the other hand, we also observe a positive (but weakly significant) association between the number of VC-backed technology-intensive start-ups and the share of governmental VC in the region. This last finding seems to suggest that GVC programs are mainly targeted to start-ups that are usually neglected by private VC investors (e.g., Bertoni et al. 2018; Cumming et al. 2017; Guerini and Quas 2016). Nevertheless, we acknowledge that our analysis is not sufficient to assess the effect of this kind of initiatives on regional VC activity. In our opinion, this is an important avenue for future research.

The analyses carried out in this paper have, however, relevant implications for policy makers who are interested in designing effective policy initiatives to stimulate the emergence of vibrant entrepreneurial ecosystems (for an in-depth discussion on this issue see, e.g., Audretsch and Belitski 2017). At the aggregated level, recent evidence suggests that there are not major differences between Europe and the U.S. as to start-up creation rates (OECD 2016). Nevertheless, the present work shows that in Europe there are relevant differences both across and within countries. Our results support the need for interventions at both the regional and the country-level aimed at overcoming the local and institutional barriers that hinder the development of a robust VC industry and, thus, the growth of entrepreneurial ecosystems. At the regional level, we welcome policy measures aimed at increasing the regional knowledge capacity (e.g., by incentivizing firm R\&D and promoting university-industry linkages), facilitating the procedures to start new businesses by prospective entrepreneurs, and improving the exit opportunities for VC investors (e.g., by reducing capital gain taxes). Several 
European countries have recently put in place a range of initiatives to create a favourable institutional environment for start-ups and VC investors. For instance, in Italy, the national Government approved at the end of 2012 the Decree Law 179/12, which provides specific measures such as tax credits to both start-ups and VC investors ${ }^{9}$. On the basis of the evidence shown in the present study, this kind of initiatives seem particularly promising.

\section{References}

Almeida, P., Dokko, G., \& Rosenkopf, L. (2003). Startup size and the mechanisms of external learning: increasing opportunity and decreasing ability? Research Policy, 32(2), 301-315.

Armour, J., \& Cumming, D. J. (2006) The legislative road to Silicon Valley, Oxford Economic Papers 58, 596-635.

Audretsch, D. B., \& Belitski, M. (2017). Entrepreneurial ecosystems in cities: establishing the framework conditions. The Journal of Technology Transfer, 42(5), 1030-1051.

Audretsch, D.B., \& Keilbach, M. (2004). Entrepreneurship capital and economic performance. Regional Studies, 38, 949-959.

Audretsch, D.B., \& Keilbach, M. (2005). Entrepreneurship capital and regional growth. Annals of Regional Science, 39, 457-469.

Balassa, B. (1965), Trade liberalization and "revealed" comparative advantage, The Manchester School of Economic and Social Studies, 33, 92-123.

Balassa, B. (1989), "Revealed" comparative advantage revisited. In B. Balassa (Ed.), Comparative Advantage, Trade Policy and Economic Development. (pp. 63-79). New York: New York University Press.

Berger, A. N., \& Udell, G. F. (1990). Collateral, loan quality and bank risk. Journal of Monetary Economics, 25(1), 21-42.

Bertoni, F., D’Adda, D., \& Grilli, L. (2018). Self-selection of entrepreneurial firms in thin venture capital markets: Theory and empirical evidence. Strategic Entrepreneurship Journal, Forthcoming.

Bertoni, F., Croce, A., \& Guerini, M. (2015a). Venture capital and the investment curve of young high-tech companies. Journal of Corporate Finance, 35, 159-176.

Bertoni, F., Colombo, M. G., \& Quas, A. (2015b). The patterns of venture capital investment in Europe. Small Business Economics, 45, 543-560.

Bertoni, F., \& Tykvová, T. (2015). Does governmental venture capital spur invention and innovation? Evidence from young European biotech companies. Research Policy, 44(4), 925-935.

\footnotetext{
${ }^{9}$ In additional estimates, we include in our econometric models a dummy variable that equals one for Italian regions for each observation subsequent to 2012. This result seems to suggest that after the implementation of this policy initiative, both the number of VC-backed technology-intensive start-ups and the number of VC investment in Italy significantly increased. Estimates are omitted here, but available upon authors' request.
} 
Bernstein, S., Giraud, X., \& Townsend, R. R. (2016). The impact of venture capital monitoring. Journal of Finance, 71, 1591-1622.

Black, B.S., \& Gilson, R.J. (1998) Venture capital and the structure of capital markets: banks versus stock markets. Journal of Financial Economics, 47, 243-277.

Carpenter, R. E., \& Petersen, B. C. (2002). Capital Market Imperfections, High-Tech Investment, and New Equity Financing, The Economic Journal, 112(477), F54-F72.

Chen, H., Gompers, P. A., Kovner, P. A., \& Lerner, J. (2010). Buy local? The geography of venture capital. Journal of Urban Economics, 67(1), 90-102.

Colombo, M. G., \& Shafi, K. (2016). Swimming with Sharks in Europe: When are They Dangerous and What Can New Ventures Do to Defend Themselves? Strategic Management Journal, 37(11), 2307-2322.

Criscuolo, C., Gal, P.N., \& Menon, C. (2014). The Dynamics of Employment Growth: New Evidence from 18 Countries. OECD Science, Technology and Industry Policy Papers, n. 14, OECD, Paris.

Croce, A., Martí, J., \& Murtinu, S. (2013). The impact of venture capital on the productivity growth of European entrepreneurial firms: 'Screening' or 'value added' effect? Journal of Business Venturing, 28(4), 489-510.

Cumming, D. J., Grilli, L., \& Murtinu, S. (2017). Governmental and independent venture capital investments in Europe: A firm-level performance analysis. Journal of Corporate Finance, 42, 439459.

Cumming, D. J., Johan, S., \& MacIntosh, J. G. (2017). A drop in an empty pond: Canadian public policy towards venture capital. Economia e Politica Industriale, 44(1) 103-117.

Cumming, D. J. \& Dai, N. (2010). Local bias in venture capital investments. Journal of Empirical Finance, 17(3), 362-380.

Cumming, D., Schmidt, D., \& Walz, U. (2010). Legality and venture capital governance around the world. Journal of Business Venturing, 25(1), 54-72.

Cumming, D. J., \& MacIntosh, J. G. (2006). Crowding out private equity: Canadian evidence. Journal of Business Venturing, 21(5), 569-609.

Da Rin, M., Hellmann, T., \& Puri, M. (2013). A Survey of Venture Capital Research. In G. M. Constantinides, M. Harris, \& R. M. Stulz (Ed.) Handbook of the Economics of Finance, (pp. 573648). Elsevier.

Denis, D. J. (2004) Entrepreneurial finance: an overview of the issues and evidence. Journal of Corporate Finance, 10(2), 301-326.

Devigne, D., Vanacker, T., Manigart, S., \& Paeleman, I. (2013). The role of domestic and crossborder venture capital investors in the growth of portfolio companies. Small Business Economics, 40, $553-573$.

European Commission (2016). Europe's next leaders: The Start-up and Scale-up Initiative. COM (2016) 733 final. https://ec.europa.eu/growth/content/europes-next-leaders-start-and-scale-initiative1_nn. Accessed 28 April 2017.

European Investment Fund (2016). The European venture capital landscape: an EIF perspective. Volume I: The impact of EIF on the VC ecosystem. Working Paper 2016/34. http://www.eif.org/news_centre/publications/eif_wp_34.pdf. Accessed 10 February 2018.

Florida, R., \& Mellander, C. (2016). Rise of the Startup City: the Changing Geography of the Venture Capital Financed Innovation, California Management Review, 59(1) 14-38. 
Florida, R., \& King, K. M. (2015). Startup City Canada: The Geography of Venture Capital and Startup Activity in Canada. November, 2015. http://martinprosperity.org/media/Startup-CityCanada.pdf. Accessed 11 February 2018.

Florida, R., \& Smith, D.F. (1993). Venture capital formation, investment, and regional industrialization. Annals of the American Association of Geographers, 83, 434-451.

Gompers, P., Lerner, J., \& Scharfstein, D. (2005). Entrepreneurial spawning: public corporations and the genesis of new ventures, 1986 to 1999. Journal of Finance. 60, 577-614.

Gompers, P. A., Levin, D. Z., \& Lerner, J. (2001). The Venture Capital Revolution. Journal of Economic Perspectives, 15(2), 145-168.

Gompers, P.A., \& Lerner, J. (1999). The Venture Capital Cycle. Cambridge, MA: MIT Press.

Gompers, P., \& Lerner, J. (1998). What drives venture fundraising? Brooking papers on economic activity. Microeconomics 149-192.

Guerini, M., \& Quas, A. (2016). Governmental venture capital in Europe: Screening and certification. Journal of Business Venturing, 31(2), 175-195.

Hausman, J., Hall, B.H., \& Griliches, Z. (1984). Econometric Models for Count Data with an Application to the Patents-R\&D Relationship. Econometrica, 52(4), 909-938.

Hofstede, G. (1991). Cultures and Organizations: Software of the Mind. Berkshire, England: McGraw-Hill.

Jeng, L.A., \& Wells, P.C. (2000) The determinants of venture capital funding: evidence across countries, Journal of Corporate Finance, 6, 241-89.

Kaplar, S. N., \& Lerner, J. (2016). Venture Capital Data: Opportunities and Challenges. NBER Working Paper No. 22500. August, 2016.

La Porta, R., Lopez-De-Silanes, F., Shleifer, A., \& Vishny, R. (1997). Legal determinants of external finance. Journal of Finance, 52, 1131-1150.

La Porta, R., Lopez-De-Silanes, F., Shleifer, A., \& Vishny, R. (1998). Law and finance. Journal of Political Economy, 106, 1113-1155.

Lerner, J. (2009). Boulevard of broken dreams: Why public efforts to boost entrepreneurship and venture capital have failed — and what to do about it. Princeton, NJ: Princeton University Press.

Li, Y., \& Zahra, S. A. (2012). Formal institutions, culture, and venture capital activity: A crosscountry analysis. Journal of Business Venturing, 27(1), 95-111.

Lindgaard Christensen, J. (2007). The Development of Geographical Specialization of Venture Capital. European Planning Studies, 15(6), 817-833.

Lutz, E., Bender, M., Achleitner, A. K., \& Kaserer, C. (2013). Importance of spatial proximity between venture capital investors and investees in Germany. Journal of Business Research, 66, 23462354.

Mäkelä, M. M., \& Maula, M. V. J. (2008). Attracting cross-border venture capital: The role of a local investor. Entrepreneurship \& Regional Development, 20, 237-257.

Martin, R., Berndt, C., Klagge, B., \& Sunley, P. (2005). Spatial proximity effects and regional equity gaps in the venture capital market: evidence from Germany and the United Kingdom. Environmental Planning, A37, 1207-1231.

Mason, C.M., \& Harrison, R.T. (2002). The geography of venture capital investments. Transactions of the Institute of British Geographers, 27, 427-451. 
Mason, C., \& Pierrakis, Y. (2013). Venture capital, the regions and public policy: The United Kingdom since the Post-2000 technology crash. Regional Studies, 47, 1156- 1171.

Mayer, C., Schoors, K., \& Yafeh, Y. (2005) Sources of funds and investment activities of venture capital funds: evidence from Germany, Israel, Japan and the UK, Journal of Corporate Finance, 11, $586-608$.

Moore, C. B., Payne, G. T., Bell, R. G., \& Davis, J. L. (2015). Institutional Distance and Cross-Border Venture Capital Investment Flows. Journal of Small Business Management, 52(2), 482-500.

OECD (2016). Entrepreneurship at a glance 2016. OECD Publishing, Paris. http://dx.doi.org/10.1787/entrepreneur_aag-2016-en. Accessed 28 April 2017.

OECD (2013). Definition of Functional Urban Areas (FUA) for the OECD metropolitan database. OECD Publishing, Paris. http://www.oecd.org/gov/regional-policy/Definition-of-Functional-UrbanAreas-for-the-OECD-metropolitan-database.pdf. Accessed 30 April 2017.

Pan, F., Zhao, S., \& Wójcik, D., (2016). The rise of venture capital centres in China: A spatial and network analysis, Geoforum, 75, 148-158.

Schertler, A. (2003). Driving forces of venture capital investments in Europe: a dynamic panel data analysis. European Integration, Financial Systems and Corporate Performance (EIFC) Working Paper No. 03-27. United Nations University.

Subhash, K. B. (2007). Geography of Venture Capital Financing in Canada, The Journal of Private Equity, 11(1), 93-107.

Sorenson, O., \& Stuart, T. E. (2001). Syndication Networks and the Spatial Distribution of Venture Capital Investments. The American Journal of Sociology, 106(6), 1546-1588.

Zhang, J. (2011). The spatial dynamics of globalizing venture capital in China. Environmental Planning. A43, 1562-1580.

Zook, M.A. (2002). Grounded capital: venture financing and the geography of the Internet industry, 1994-2000. Journal of Economic Geography, 2(2), 151-177. 


\section{Tables}

Table 1 Distribution of new technology-based firms in VICO 2.0 by industry

\begin{tabular}{lrrr}
\hline & NACE code & N. & Percent. \\
\hline High-technology manufacturing & & & \\
$\quad$ Manufacture of pharmaceutical products and preparations & 21 & 99 & 2.54 \\
$\quad$ Manufacture of computer, electronic and optical products & 26 & 256 & 6.57 \\
Medium-high-technology manufacturing & & & \\
$\quad$ Manufacture of chemicals and chemical products & 20 & 51 & 1.31 \\
$\quad$ Manufacture of electrical equipment & 27 & 62 & 1.59 \\
$\quad$ Manufacture of machinery and equipment & 28 & 95 & 2.44 \\
Manufacture of motor vehicles, trailers and semi-trailers & 29 & 12 & 0.31 \\
$\quad$ Manufacture of other transport equipment & 30 & 21 & 0.54 \\
High-tech knowledge intensive services & & & \\
Motion picture, video production, and music publishing activities & 59 & 74 & 1.90 \\
Programming and broadcasting activities & 60 & 26 & 0.67 \\
Telecommunications & 61 & 205 & 5.26 \\
Computer programming, consultancy and related activities & 62 & 1,918 & 49.23 \\
Information service activities & 63 & 306 & 7.85 \\
Scientific research and development & 72 & 771 & 19.79 \\
\hline Total & & $\mathbf{3 , 8 9 6}$ & $\mathbf{1 0 0}$ \\
\hline
\end{tabular}

Table 2 Number of new technology-based firms, VC investment deals and total VC investment amount by country

\begin{tabular}{|c|c|c|c|c|c|c|}
\hline \multirow[t]{2}{*}{ Country } & \multicolumn{2}{|c|}{ Technology-intensive start-ups } & \multicolumn{2}{|c|}{ Investment deals } & \multicolumn{2}{|c|}{ Investment Amount } \\
\hline & N. & Percent. & N. & Percent. & Thousand $€$ & Percent. \\
\hline United Kingdom & 1,448 & 37.17 & 2,770 & 39.35 & $15,464,104$ & 46.37 \\
\hline Germany & 969 & 24.87 & 1,720 & 24.43 & $7,450,183$ & 22.34 \\
\hline France & 714 & 18.33 & 1,302 & 18.49 & $5,368,805$ & 16.10 \\
\hline Spain & 258 & 6.62 & 345 & 4.90 & $1,882,912$ & 5.65 \\
\hline Finland & 253 & 6.49 & 526 & 7.47 & 856,935 & 2.57 \\
\hline Italy & 142 & 3.64 & 171 & 2.43 & 932,799 & 2.80 \\
\hline Belgium & 112 & 2.87 & 206 & 2.93 & $1,391,465$ & 4.17 \\
\hline Total & 3,896 & 100 & 7,040 & 100 & $33,347,203$ & 100 \\
\hline
\end{tabular}

Table 3 Mean and median VC investment amount per deal by country

\begin{tabular}{lcc}
\hline Country & Mean per deal $^{*}$ & Median per deal $^{*}$ \\
\hline Belgium & 6,575 & 2,773 \\
Germany & 6,528 & 3,067 \\
Italy & 5,610 & 1,019 \\
United Kingdom & 5,057 & 1,866 \\
Spain & 4,828 & 1,000 \\
France & 3,617 & 1,736 \\
Finland & 1,955 & 480 \\
\hline
\end{tabular}

*Figures in thousands $€$ 
Table 4 Performance by FUA (top 10 FUAs)

\begin{tabular}{lrr}
\hline Country & $\begin{array}{r}\text { Early stage growth } \\
\text { Percent }\end{array}$ & $\begin{array}{r}\text { Successful exit } \\
\text { Percent }\end{array}$ \\
\hline London & 26.7 & 28.6 \\
Paris & 37.0 & 19.8 \\
Berlin & 26.2 & 14.9 \\
Muenchen & 23.3 & 24.2 \\
Helsinki & 17.9 & 20.3 \\
Cambridge & 38.9 & 34.4 \\
Barcelona & 24.5 & 8.5 \\
Hamburg & 33.3 & 20.8 \\
Edinburgh & 6.5 & 22.7 \\
Madrid & 43.3 & 20.5 \\
\hline
\end{tabular}

Table 5 Variable Description

\begin{tabular}{|c|c|}
\hline Variable & Description \\
\hline \multicolumn{2}{|l|}{ Dependent variables } \\
\hline VC investments & Number of VC investments in each region/year (source: VICO 2.0). \\
\hline VC-backed start-ups & Number of VC-backed technology intensive start-ups in each region/year (source: VICO 2.0). \\
\hline \multicolumn{2}{|l|}{ Independent variables } \\
\hline GDP per capita & Gross domestic product per number of inhabitants in each region/year (source: Eurostat). \\
\hline Population density & Number of inhabitants per square km in each region/year (source: Eurostat). \\
\hline Metropolitan area & $\begin{array}{l}\text { Dummy that equals } 1 \text { if in the region there is at least one metropolitan area among the top } 20 \\
\text { Functional Urban Areas in the sample (source: OECD). }\end{array}$ \\
\hline R\&D expenditures & $\begin{array}{l}\text { R\&D expenditures in each region/year divided by the regional gross domestic product per } \\
\text { capita (source: Eurostat). }\end{array}$ \\
\hline Top university & $\begin{array}{l}\text { Number of universities in each region ranked among the top } 100 \text { world universities (source: } \\
\text { QS World University Rankings 2010). }\end{array}$ \\
\hline $\begin{array}{l}\text { Technology-intensive } \\
\text { employment }\end{array}$ & $\begin{array}{l}\text { Percentage of employees in high-technology manufacturing and knowledge-intensive service } \\
\text { sectors in each region/year (Eurostat). }\end{array}$ \\
\hline Active VCs & $\begin{array}{l}\text { Number of VC investors that have made at least one investment in each region/year (source: } \\
\text { VICO 2.0). }\end{array}$ \\
\hline VC offices & Number of VC investors with an office in each region/year (source: VICO 2.0). \\
\hline GVC funding & $\begin{array}{l}\text { Ratio between the number of investments made by governmental VC investors and the } \\
\text { number of total VC investments in each region cumulated over 3-year period (source: VICO } \\
\text { 2.0). }\end{array}$ \\
\hline Legal index & $\begin{array}{l}\text { Average of the six components of the World Governance Index in each country/year: } \\
\text { government effectiveness, voice and accountability, regulatory policies, rule of law, political } \\
\text { stability, control of corruption (source: World Bank). }\end{array}$ \\
\hline Tax & $\begin{array}{l}\text { Level of taxation on income and capital gains in each country/year (source: International } \\
\text { Monetary Fund). }\end{array}$ \\
\hline Time to start-up & $\begin{array}{l}\text { Average time in days required to start a new business in each country/year (source: Word } \\
\text { Bank). }\end{array}$ \\
\hline Listed companies & $\begin{array}{l}\text { Number of domestic listed companies divided by the gross domestic product in each } \\
\text { country/year (source: World Bank). }\end{array}$ \\
\hline Uncertainty avoidance & $\begin{array}{l}\text { Degree to which the members of each country feel uncomfortable with uncertainty. 0-100 } \\
\text { scale (source: https://www.hofstede-insights.com). }\end{array}$ \\
\hline Individualism & $\begin{array}{l}\text { Degree of individualism versus collectivism in each country. 0-100 scale (source: } \\
\text { https://www.hofstede-insights.com). }\end{array}$ \\
\hline Long-term orientation & $\begin{array}{l}\text { Degree of long-term versus short term normative orientation in each country. 0-100 scale } \\
\text { (source: https://www.hofstede-insights.com). }\end{array}$ \\
\hline
\end{tabular}


Table 6 Summary Statistics

\begin{tabular}{lrrrrr}
\hline Variable & N. & Mean & S.D. & Min & Max \\
\hline VC investments & 1,384 & 8.5 & 35 & 0 & 647 \\
VC-backed start-ups & 1,384 & 2.3 & 10 & 0 & 191 \\
GDP per capita & 1,384 & 28,208 & 7,817 & 13,100 & 62,900 \\
Population density & 1,384 & 468 & 1,001 & 6.4 & 7,393 \\
Metropolitan area & 1,384 & .12 & .33 & 0 & 1 \\
R\&D expenditures & 1,284 & 1.7 & 1.2 & .06 & 8.8 \\
Top university & 1,384 & .18 & .52 & 0 & 4 \\
Technology-intensive & 1,222 & 3.7 & 1.7 & 1 & 12 \\
employment & 1,384 & 6.5 & 24 & 0 & 441 \\
Active VCs & 1,384 & 18 & 60 & 0 & 608 \\
VC offices & 1,384 & .06 & .16 & 0 & 1 \\
GVC funding & 1,384 & 1.2 & .33 & .47 & 2 \\
Legal index & 1,384 & 28 & 9.1 & 15 & 50 \\
Tax & 1,384 & 17 & 19 & 4 & 137 \\
Time to start-up & 1,363 & 4.8 & 4.8 & .18 & 22 \\
Listed companies & 1,384 & 67 & 20 & 35 & 94 \\
Uncertainty avoidance & 1,384 & 73 & 11 & 51 & 89 \\
Individualism & 1,384 & 65 & 14 & 38 & 83 \\
Long-term orientation & & & &
\end{tabular}


Table 7 Correlation Matrix

\begin{tabular}{|c|c|c|c|c|c|c|c|c|c|c|c|c|c|c|c|c|c|}
\hline & 1 & 2 & 3 & 4 & 5 & 6 & 7 & 8 & 9 & 10 & 11 & 12 & 13 & 14 & 15 & 16 & 17 \\
\hline 1. VC investments & 1.00 & & & & & & & & & & & & & & & & \\
\hline $\begin{array}{l}\text { 2. VC-backed start- } \\
\text { Ups }\end{array}$ & $0.97 *$ & 1.00 & & & & & & & & & & & & & & & \\
\hline 3. GDP per capita & $0.37 *$ & $0.33 *$ & 1.00 & & & & & & & & & & & & & & \\
\hline 4. Population density & $0.36^{*}$ & $0.36^{*}$ & $0.32 *$ & 1.00 & & & & & & & & & & & & & \\
\hline 5. Metropolitan area & $0.35^{*}$ & $0.32 *$ & $0.45^{*}$ & $0.43^{*}$ & 1.00 & & & & & & & & & & & & \\
\hline 6. $R \& D$ expenditures & $0.13^{*}$ & $0.07 *$ & $0.44^{*}$ & -0.03 & $0.21 *$ & 1.00 & & & & & & & & & & & \\
\hline 7. Top university & $0.67 *$ & $0.63^{*}$ & $0.38 *$ & $0.34 *$ & $0.35^{*}$ & $0.20 *$ & 1.00 & & & & & & & & & & \\
\hline $\begin{array}{l}\text { 8. Technology- } \\
\text { intensive } \\
\text { employment }\end{array}$ & $0.32 *$ & $0.26^{*}$ & $0.62 *$ & $0.27 *$ & $0.43 *$ & $0.61 *$ & $0.39 *$ & 1.00 & & & & & & & & & \\
\hline 9. Active VCs & $0.99 *$ & $0.95 *$ & $0.38^{*}$ & $0.37 *$ & $0.35^{*}$ & $0.14 *$ & $0.68 *$ & $0.33^{*}$ & 1.00 & & & & & & & & \\
\hline 10. VC offices & $0.84 *$ & $0.81 *$ & $0.44^{*}$ & $0.40 *$ & $0.52 *$ & $0.11 *$ & $0.72 *$ & $0.35^{*}$ & $0.84^{*}$ & 1.00 & & & & & & & \\
\hline 11. GVC funding & -0.03 & -0.02 & $0.07 *$ & -0.05 & -0.03 & $0.09 *$ & $-0.07 *$ & 0.02 & -0.03 & -0.04 & 1.00 & & & & & & \\
\hline 12. Tax & 0.01 & 0.03 & $-0.18^{*}$ & $0.11^{*}$ & $-0.07 *$ & $-0.35^{*}$ & $0.11^{*}$ & $-0.15^{*}$ & 0.01 & 0.03 & $-0.17 *$ & 1.00 & & & & & \\
\hline 13. Legal index & $0.10^{*}$ & $0.08^{*}$ & $0.27 *$ & $0.06^{*}$ & 0.01 & $0.35^{*}$ & $0.20 *$ & $0.36^{*}$ & $0.10^{*}$ & $0.05^{*}$ & $0.14^{*}$ & $-0.38^{*}$ & 1.00 & & & & \\
\hline 14. Time to start-up & $-0.07 *$ & -0.10 & $-0.23 *$ & 0.05 & 0.01 & $-0.14 *$ & $-0.11 *$ & $-0.14 *$ & $-0.07 *$ & -0.02 & 0.01 & $0.24 *$ & $-0.10 *$ & 1.00 & & & \\
\hline 15. Listed companies & -0.05 & -0.03 & $-0.38 *$ & $0.09 *$ & $-0.12 *$ & $-0.29 *$ & 0.04 & $-0.21 *$ & -0.05 & $-0.06^{*}$ & $-0.09 *$ & $0.57 *$ & -0.02 & $0.48^{*}$ & 1.00 & & \\
\hline $\begin{array}{l}\text { 16. Uncertainty } \\
\text { Avoidance }\end{array}$ & $-0.13^{*}$ & $-0.13 *$ & $-0.22 *$ & -0.04 & 0.01 & $-0.11 *$ & $-0.36^{*}$ & $-0.21 *$ & $-0.14 *$ & $-0.06^{*}$ & 0.02 & $-0.09 *$ & $-0.47 *$ & $0.24 *$ & $-0.18^{*}$ & 1.00 & \\
\hline 17. Individualism & $0.12 *$ & $0.10 *$ & $0.20 *$ & 0.02 & -0.04 & $0.07 *$ & $0.31^{*}$ & $0.19 *$ & $0.13^{*}$ & $0.06^{*}$ & $-0.14 *$ & $0.22 *$ & $0.19 *$ & $-0.56^{*}$ & $-0.19 *$ & $-0.70 *$ & 1.00 \\
\hline $\begin{array}{l}\text { 18. Long-term } \\
\text { orientation }\end{array}$ & $-0.07^{*}$ & $-0.07 *$ & $0.16^{*}$ & 0.02 & 0.04 & $0.30 *$ & $-0.15^{*}$ & $0.11 *$ & $-0.06^{*}$ & $-0.06^{*}$ & $0.12^{*}$ & $-0.66^{*}$ & $0.18^{*}$ & $-0.12 *$ & $-0.63 *$ & $0.30 *$ & $-0.16^{*}$ \\
\hline
\end{tabular}

Significance level: $* \mathrm{p}<0.01$. 
Table 8 Results of econometric estimates: number of regional VC investments

\begin{tabular}{|c|c|c|c|c|c|c|}
\hline & (1) & (2) & (3) & (4) & (5) & (6) \\
\hline GDP per capita & $\begin{array}{l}-0.009 \\
(0.062)\end{array}$ & $\begin{array}{c}0.000 \\
(0.058)\end{array}$ & $\begin{array}{c}0.080 \\
(0.066)\end{array}$ & $\begin{array}{c}0.004 \\
(0.065)\end{array}$ & $\begin{array}{c}0.026 \\
(0.061)\end{array}$ & $\begin{array}{l}0.117^{*} \\
(0.068)\end{array}$ \\
\hline Population density & $\begin{array}{c}-0.177 * * \\
(0.086)\end{array}$ & $\begin{array}{c}-0.202 * * * \\
(0.074)\end{array}$ & $\begin{array}{c}-0.246 * * * \\
(0.074)\end{array}$ & $\begin{array}{l}-0.122 \\
(0.085)\end{array}$ & $\begin{array}{c}-0.171 * * \\
(0.076)\end{array}$ & $\begin{array}{c}-0.200 * * * \\
(0.077)\end{array}$ \\
\hline Metropolitan area & $\begin{array}{c}1.339 * * * \\
(0.256)\end{array}$ & $\begin{array}{c}1.576^{* * *} \\
(0.235)\end{array}$ & $\begin{array}{c}1.660 * * * \\
(0.248)\end{array}$ & $\begin{array}{c}1.289^{* * *} \\
(0.252)\end{array}$ & $\begin{array}{c}1.563 * * * \\
(0.244)\end{array}$ & $\begin{array}{c}1.613^{* * *} \\
(0.254)\end{array}$ \\
\hline R\&D expenditures & $\begin{array}{c}0.178 * * * \\
(0.067)\end{array}$ & $\begin{array}{c}0.308 * * * \\
(0.062)\end{array}$ & $\begin{array}{c}0.280^{* * *} \\
(0.065)\end{array}$ & $\begin{array}{c}0.189 * * * \\
(0.065)\end{array}$ & $\begin{array}{c}0.306 * * * \\
(0.062)\end{array}$ & $\begin{array}{c}0.290 * * * \\
(0.064)\end{array}$ \\
\hline Top university & $\begin{array}{c}0.189 * * * \\
(0.060)\end{array}$ & $\begin{array}{c}0.196 * * * \\
(0.067)\end{array}$ & $\begin{array}{c}0.274 * * * \\
(0.094)\end{array}$ & $\begin{array}{l}0.121^{*} \\
(0.063)\end{array}$ & $\begin{array}{l}0.121 * \\
(0.071)\end{array}$ & $\begin{array}{l}0.183^{*} \\
(0.101)\end{array}$ \\
\hline Technology-intensive employment & $\begin{array}{c}0.333 * * * \\
(0.062)\end{array}$ & & & $\begin{array}{c}0.317 * * * \\
(0.062)\end{array}$ & & \\
\hline Active VCs & & $\begin{array}{c}0.132 * * * \\
(0.016)\end{array}$ & & & $\begin{array}{c}0.123 * * * \\
(0.016)\end{array}$ & \\
\hline VC offices & & & $\begin{array}{l}-0.114 \\
(0.080)\end{array}$ & & & $\begin{array}{l}-0.108 \\
(0.084)\end{array}$ \\
\hline GVC funding & $\begin{array}{l}-0.032 \\
(0.036)\end{array}$ & $\begin{array}{l}-0.014 \\
(0.035)\end{array}$ & $\begin{array}{l}-0.017 \\
(0.035)\end{array}$ & $\begin{array}{l}-0.014 \\
(0.036)\end{array}$ & $\begin{array}{l}-0.008 \\
(0.035)\end{array}$ & $\begin{array}{l}-0.006 \\
(0.036)\end{array}$ \\
\hline Legal index & $\begin{array}{c}0.270^{* * *} \\
(0.090)\end{array}$ & $\begin{array}{c}0.298 * * * \\
(0.088)\end{array}$ & $\begin{array}{c}0.272 * * * \\
(0.093)\end{array}$ & $\begin{array}{c}0.384 * * * \\
(0.112)\end{array}$ & $\begin{array}{c}0.253^{* * *} \\
(0.103)\end{array}$ & $\begin{array}{c}0.241^{* *} \\
(0.106)\end{array}$ \\
\hline Tax & $\begin{array}{l}-0.042 \\
(0.082)\end{array}$ & $\begin{array}{l}-0.007 \\
(0.081)\end{array}$ & $\begin{array}{l}-0.049 \\
(0.083)\end{array}$ & $\begin{array}{l}-0.079 \\
(0.134)\end{array}$ & $\begin{array}{l}-0.038 \\
(0.126)\end{array}$ & $\begin{array}{l}-0.156 \\
(0.129)\end{array}$ \\
\hline Time to start-up & $\begin{array}{c}-0.177 * * \\
(0.090)\end{array}$ & $\begin{array}{c}-0.314 * * * \\
(0.069)\end{array}$ & $\begin{array}{c}-0.306^{* * * *} \\
(0.072)\end{array}$ & $\begin{array}{l}-0.159 \\
(0.120)\end{array}$ & $\begin{array}{c}-0.287 * * * * \\
(0.089)\end{array}$ & $\begin{array}{c}-0.240 * * * \\
(0.091)\end{array}$ \\
\hline Listed companies & $\begin{array}{c}0.280 * * * \\
(0.096)\end{array}$ & $\begin{array}{c}0.290^{* * *} \\
(0.098)\end{array}$ & $\begin{array}{c}0.328 * * * \\
(0.101)\end{array}$ & $\begin{array}{l}-0.107 \\
(0.177)\end{array}$ & $\begin{array}{c}0.029 \\
(0.154)\end{array}$ & $\begin{array}{c}0.087 \\
(0.159)\end{array}$ \\
\hline Uncertainty avoidance & & & & $\begin{array}{l}-0.193 \\
(0.168)\end{array}$ & $\begin{array}{c}-0.313^{* *} \\
(0.152)\end{array}$ & $\begin{array}{l}-0.218 \\
(0.154)\end{array}$ \\
\hline Individualism & & & & $\begin{array}{l}-0.249 \\
(0.221)\end{array}$ & $\begin{array}{l}-0.172 \\
(0.189)\end{array}$ & $\begin{array}{l}-0.071 \\
(0.194)\end{array}$ \\
\hline Long-term orientation & & & & $\begin{array}{c}-0.473 * * * \\
(0.132)\end{array}$ & $\begin{array}{c}-0.248 * * \\
(0.115)\end{array}$ & $\begin{array}{c}-0.331 * * * \\
(0.121)\end{array}$ \\
\hline Year dummies & Yes & Yes & Yes & Yes & Yes & Yes \\
\hline Log-Likelihood & $-2,644.13$ & $-2,847.92$ & $-2,863.17$ & $-2,636.41$ & $-2,840.95$ & $-2,855.12$ \\
\hline Chi2 & 285.61 & 392.26 & 261.31 & 315.06 & 409.62 & 280.95 \\
\hline N. of observations & 1,222 & 1,384 & 1,384 & 1,222 & 1,384 & 1,384 \\
\hline
\end{tabular}


Table 9 Results of econometric estimates: number of regional VC-backed start-ups

\begin{tabular}{|c|c|c|c|c|c|c|}
\hline & (1) & (2) & (3) & (4) & (5) & (6) \\
\hline GDP per capita & $\begin{array}{l}-0.043 \\
(0.071)\end{array}$ & $\begin{array}{l}-0.052 \\
(0.061)\end{array}$ & $\begin{array}{l}-0.012 \\
(0.075)\end{array}$ & $\begin{array}{l}-0.010 \\
(0.066)\end{array}$ & $\begin{array}{l}-0.043 \\
(0.062)\end{array}$ & $\begin{array}{c}0.015 \\
(0.071)\end{array}$ \\
\hline Population density & $\begin{array}{l}-0.075 \\
(0.119)\end{array}$ & $\begin{array}{l}-0.149 \\
(0.092)\end{array}$ & $\begin{array}{l}-0.185^{*} \\
(0.100)\end{array}$ & $\begin{array}{c}0.053 \\
(0.113)\end{array}$ & $\begin{array}{l}-0.105 \\
(0.090)\end{array}$ & $\begin{array}{l}-0.075 \\
(0.110)\end{array}$ \\
\hline Metropolitan area & $\begin{array}{c}1.279 * * * \\
(0.294)\end{array}$ & $\begin{array}{c}1.657 * * * \\
(0.284)\end{array}$ & $\begin{array}{c}1.584 * * * \\
(0.314)\end{array}$ & $\begin{array}{c}1.171 * * * \\
(0.260)\end{array}$ & $\begin{array}{c}1.595 * * * \\
(0.276)\end{array}$ & $\begin{array}{c}1.442 * * * \\
(0.307)\end{array}$ \\
\hline R\&D expenditures & $\begin{array}{c}0.070 \\
(0.083)\end{array}$ & $\begin{array}{c}0.211 * * * \\
(0.080)\end{array}$ & $\begin{array}{c}0.215^{* *} \\
(0.085)\end{array}$ & $\begin{array}{c}0.081 \\
(0.076)\end{array}$ & $\begin{array}{c}0.227 * * * \\
(0.077)\end{array}$ & $\begin{array}{c}0.252^{* * * *} \\
(0.082)\end{array}$ \\
\hline Top university & $\begin{array}{c}0.201 * * * \\
(0.075)\end{array}$ & $\begin{array}{c}0.332 * * * \\
(0.083)\end{array}$ & $\begin{array}{c}0.229 * * \\
(0.113)\end{array}$ & $\begin{array}{c}0.232 * * * \\
(0.080)\end{array}$ & $\begin{array}{c}0.314 * * * \\
(0.085)\end{array}$ & $\begin{array}{c}0.187 \\
(0.116)\end{array}$ \\
\hline Technology-intensive employment & $\begin{array}{c}0.374 * * * \\
(0.066)\end{array}$ & & & $\begin{array}{c}0.340 * * * \\
(0.062)\end{array}$ & & \\
\hline Active VCs & & $\begin{array}{c}0.123 * * * \\
(0.015)\end{array}$ & & & $\begin{array}{c}0.114 * * * \\
(0.016)\end{array}$ & \\
\hline VC offices & & & $\begin{array}{l}-0.028 \\
(0.101)\end{array}$ & & & $\begin{array}{c}0.016 \\
(0.112)\end{array}$ \\
\hline GVC funding & $\begin{array}{c}0.055 \\
(0.043)\end{array}$ & $\begin{array}{l}0.071 * \\
(0.042)\end{array}$ & $\begin{array}{c}0.066 \\
(0.043)\end{array}$ & $\begin{array}{l}0.083^{*} \\
(0.042)\end{array}$ & $\begin{array}{l}0.078^{*} \\
(0.042)\end{array}$ & $\begin{array}{c}0.087 * * \\
(0.043)\end{array}$ \\
\hline Legal index & $\begin{array}{c}0.294 * * * \\
(0.106)\end{array}$ & $\begin{array}{c}0.311^{* * *} \\
(0.098)\end{array}$ & $\begin{array}{c}0.306 * * * \\
(0.105)\end{array}$ & $\begin{array}{c}0.463 * * * \\
(0.117)\end{array}$ & $\begin{array}{c}0.349 * * * \\
(0.108)\end{array}$ & $\begin{array}{c}0.306^{* * * *} \\
(0.112)\end{array}$ \\
\hline Tax & $\begin{array}{l}-0.048 \\
(0.102)\end{array}$ & $\begin{array}{c}0.028 \\
(0.098)\end{array}$ & $\begin{array}{l}-0.041 \\
(0.106)\end{array}$ & $\begin{array}{l}-0.256^{*} \\
(0.138)\end{array}$ & $\begin{array}{l}-0.055 \\
(0.138)\end{array}$ & $\begin{array}{c}-0.334 * * \\
(0.153)\end{array}$ \\
\hline Time to start-up & $\begin{array}{c}0.024 \\
(0.105)\end{array}$ & $\begin{array}{c}-0.169 * * \\
(0.081)\end{array}$ & $\begin{array}{l}-0.140 \\
(0.089)\end{array}$ & $\begin{array}{c}0.164 \\
(0.125)\end{array}$ & $\begin{array}{l}-0.138 \\
(0.098)\end{array}$ & $\begin{array}{c}0.010 \\
(0.104)\end{array}$ \\
\hline Listed companies & $\begin{array}{c}0.064 \\
(0.110)\end{array}$ & $\begin{array}{c}0.055 \\
(0.107)\end{array}$ & $\begin{array}{c}0.070 \\
(0.115)\end{array}$ & $\begin{array}{l}-0.132 \\
(0.182)\end{array}$ & $\begin{array}{l}-0.078 \\
(0.155)\end{array}$ & $\begin{array}{c}0.027 \\
(0.165)\end{array}$ \\
\hline Uncertainty avoidance & & & & $\begin{array}{c}0.246 \\
(0.180)\end{array}$ & $\begin{array}{c}0.024 \\
(0.168)\end{array}$ & $\begin{array}{c}0.200 \\
(0.176)\end{array}$ \\
\hline Individualism & & & & $\begin{array}{c}0.069 \\
(0.224)\end{array}$ & $\begin{array}{l}-0.049 \\
(0.194)\end{array}$ & $\begin{array}{c}0.248 \\
(0.206)\end{array}$ \\
\hline $\begin{array}{l}\text { Long-term orientation } \\
\text { Year dummies }\end{array}$ & Yes & Yes & Yes & $\begin{array}{c}-0.590 * * * \\
(0.138) \\
\text { Yes }\end{array}$ & $\begin{array}{c}-0.295^{* *} \\
(0.124) \\
\text { Yes }\end{array}$ & $\begin{array}{c}-0.425 * * * \\
(0.132) \\
\text { Yes }\end{array}$ \\
\hline Log-Likelihood & $-1,620.74$ & $-1,719.52$ & $-1,745.87$ & $-1,612.07$ & $-1,716.76$ & $-1,740.21$ \\
\hline Chi2 & 201.85 & 284.26 & 185.89 & 233.70 & 299.32 & 207.55 \\
\hline N. of observations & 1,222 & 1,384 & 1,384 & 1,222 & 1,384 & 1,384 \\
\hline
\end{tabular}


Figures

Figure 1 Industry specialization - Balassa indexes by country

Manufacture of pharmaceutical products and preparations -21

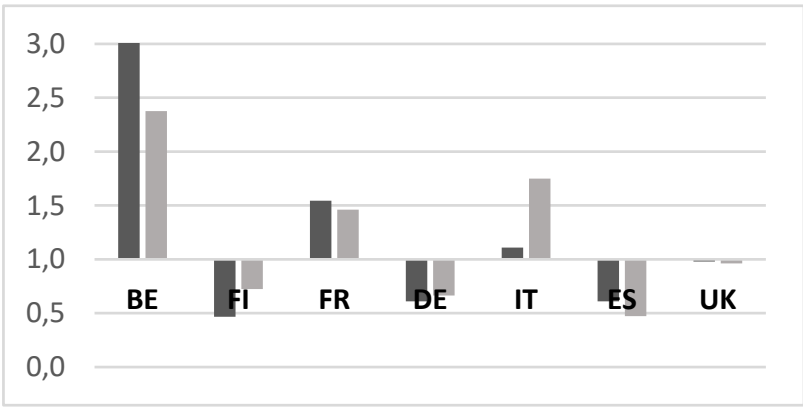

Telecommunications - 61

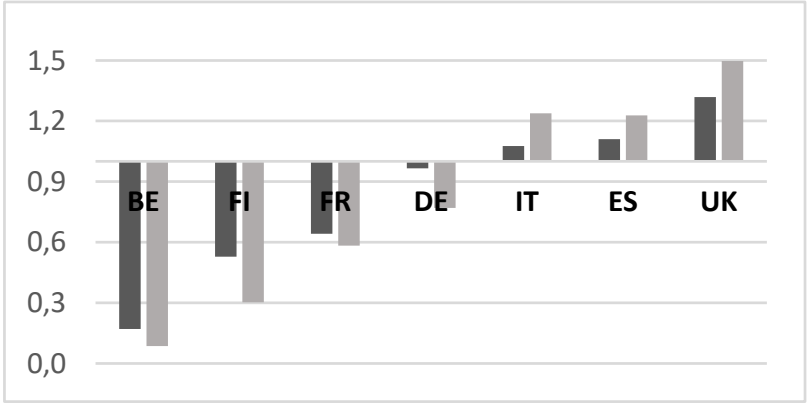

Information service activities -63

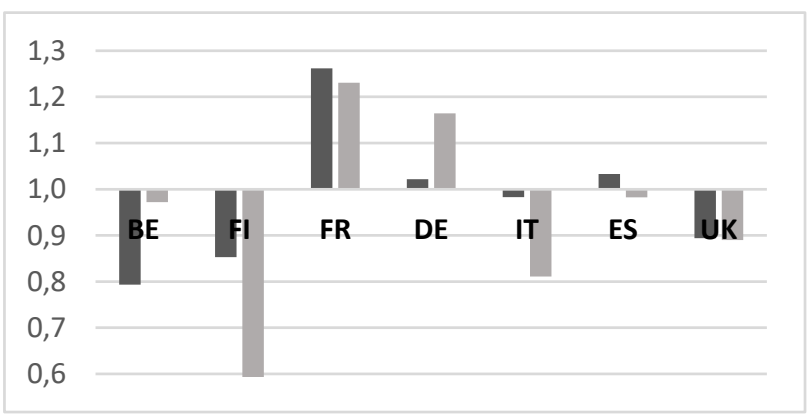

Other Manufacturing

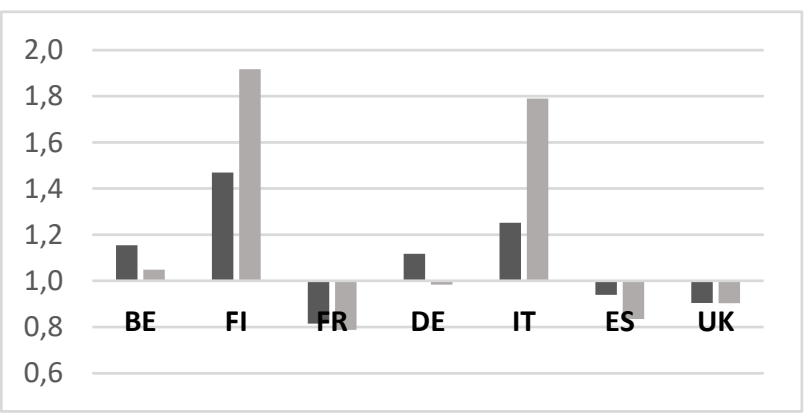

Manufacture of computer, electronic and optical products -26

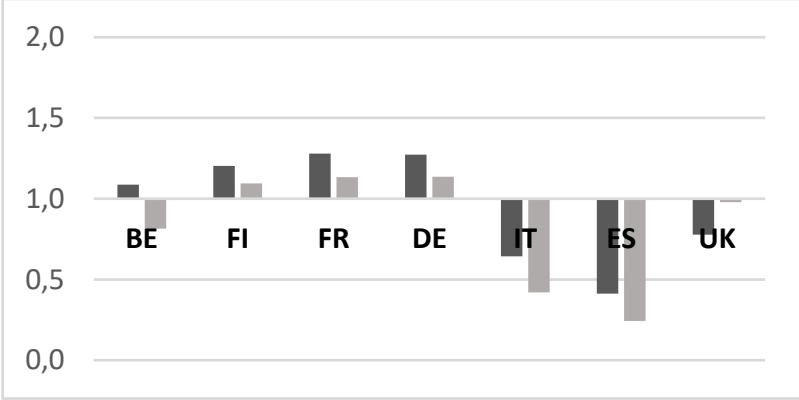

Computer programming, consultancy and related activities -62



Scientific research and development -72

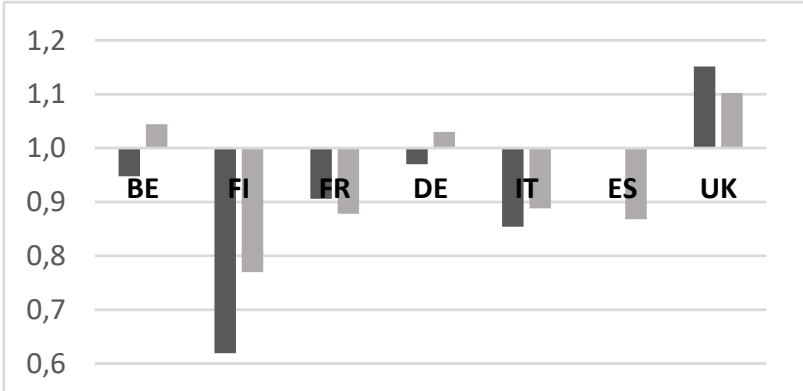

Other Services




Figure 2 Distribution of technology-intensive start-up by FUA - Northern Europe

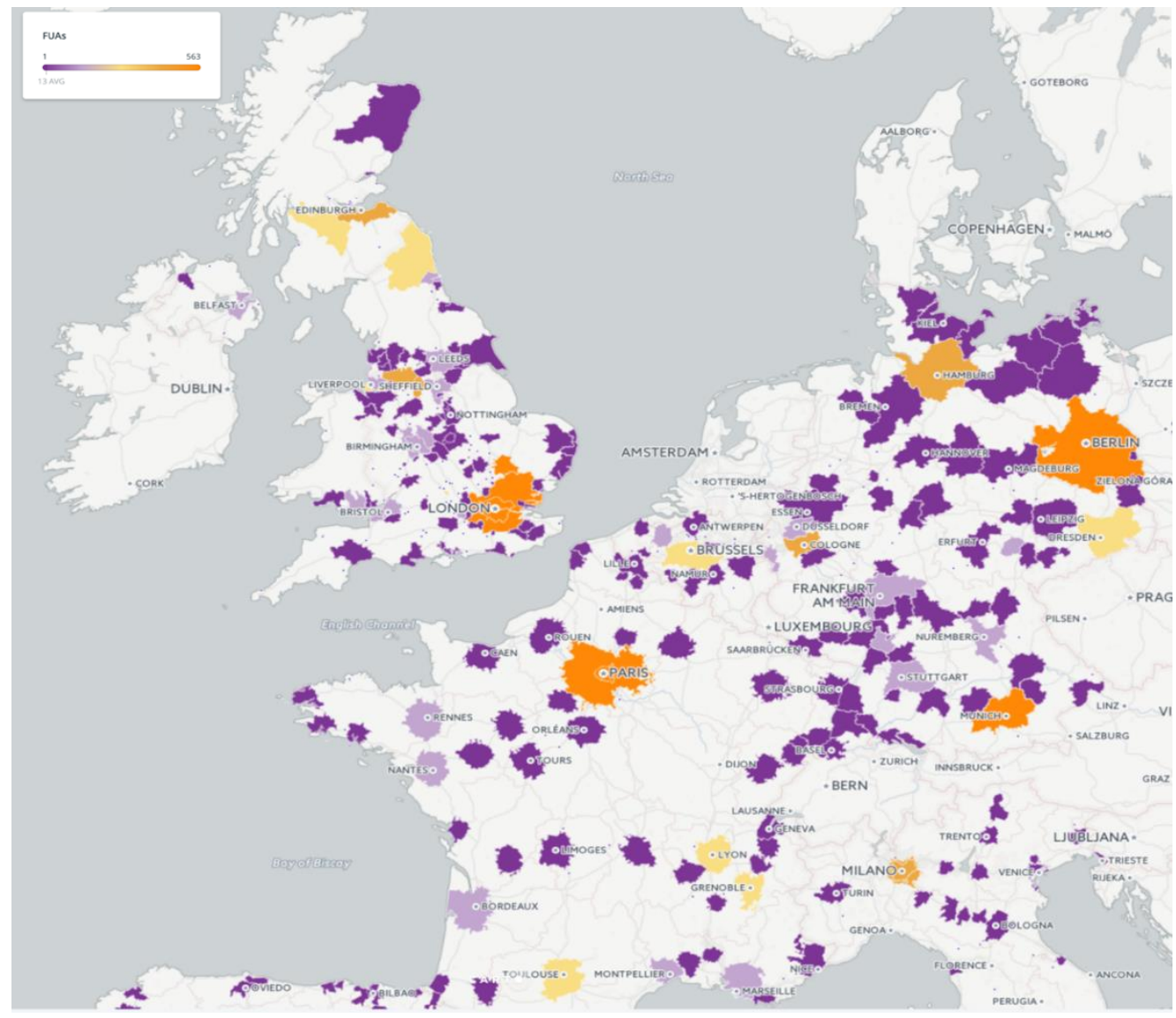

Figure 3 Distribution of technology-intensive start-ups by FUA - Finland

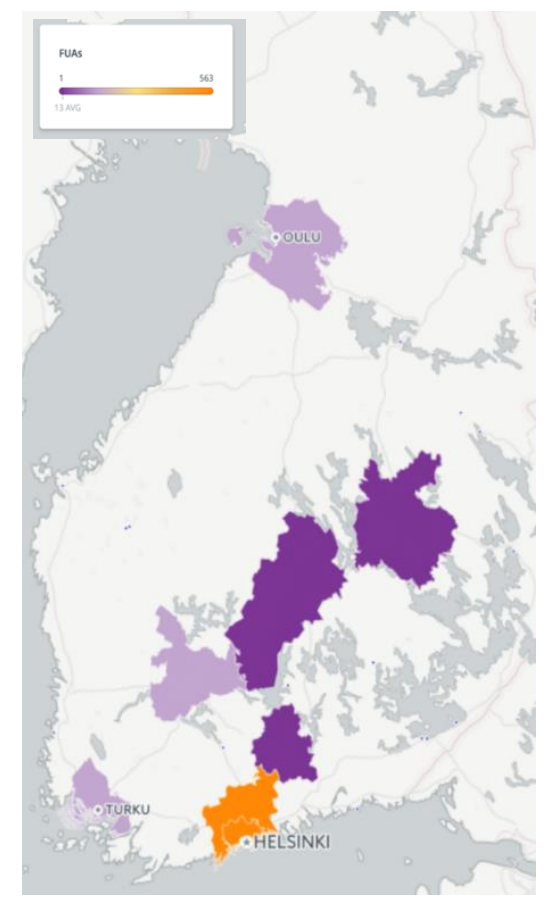


Figure 4 Distribution of technology-intensive start-ups by FUA - Sothern Europe

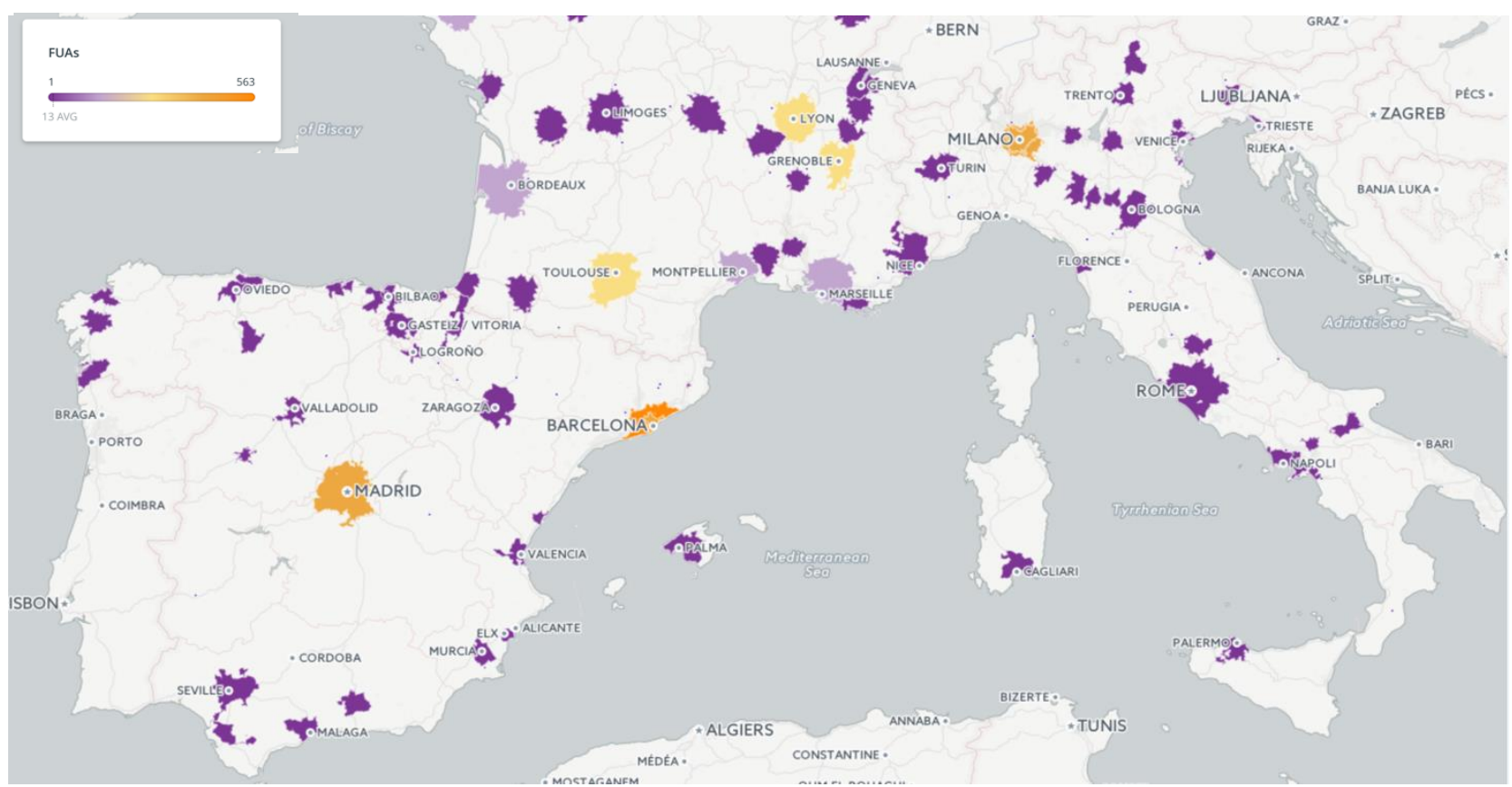

Figure 5 Distribution of technology-intensive start-ups and investment deals by FUAs

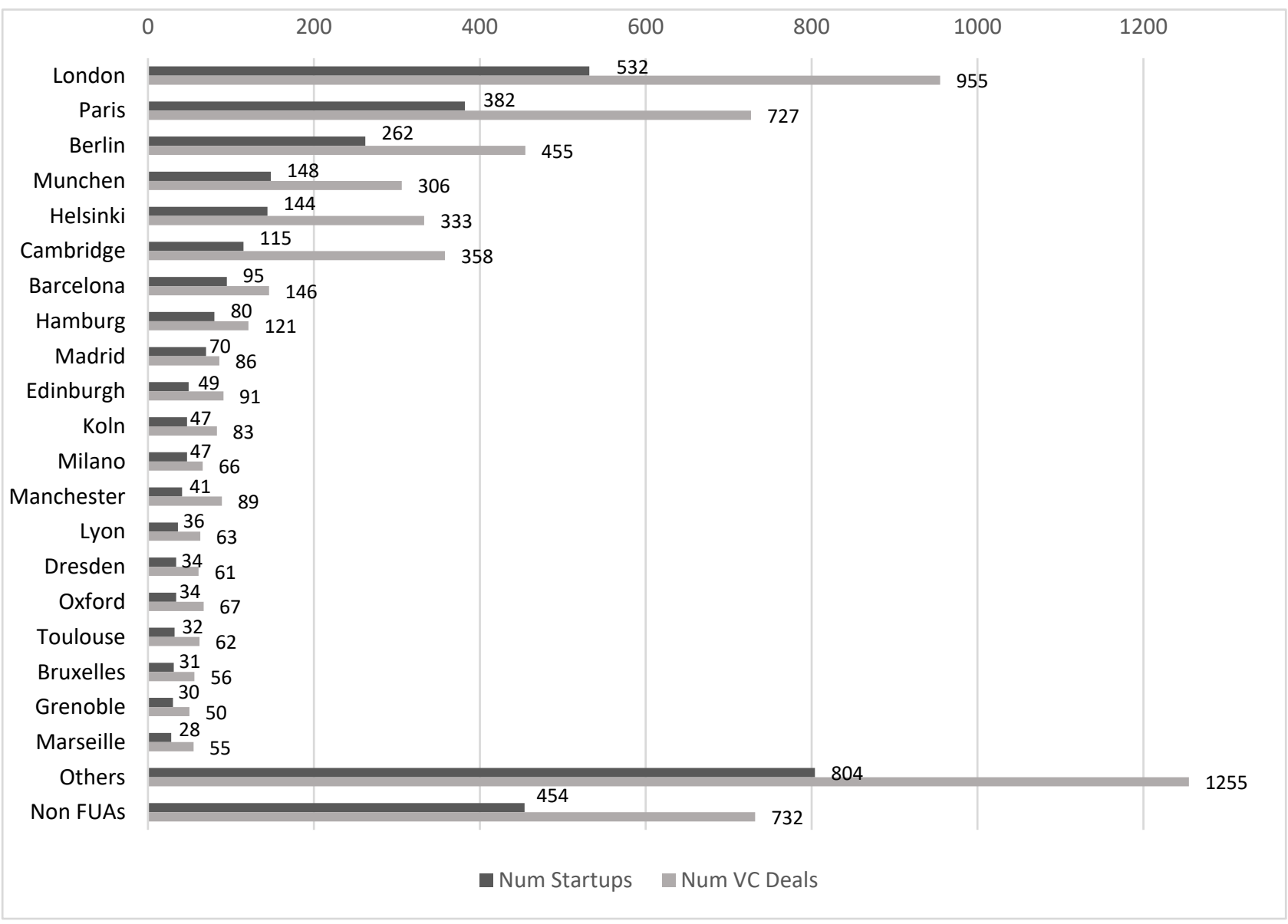

